antibiotics carry a high risk of causing allergic reactions, and this is particularly true of penicillin and the aminoglycoside antibiotics, neomycin and framycetin. Moreover, the incidence of staphylococcal resistance to penicillin and neomycin seems to be increasing. We eventually decided to use tetracycline, but for pharmaceutical reasons a suitable formulation was difficult to prepare.

Topical sodium fusidate does not seem to have these disadvantages. In the present trial sodium fusidate applied by either method was free of adverse reactions. This is also in accord with previous reports which recorded the use of sodium fusidate ointment and impregnated paraffin gauze sodium fusidate in 1,010 and 250 patients respectively (Ritchie, 1966, 1968). Topical sodium fusidate has been used in this department during the past seven years in over 10,000 cases without adverse effect. S $\phi$ bye (1966) treated 427 dermatological infections with sodium fusidate ointment but encountered no instances of hypersensitivity.

Of the total of 1,330 swabs examined, only on four occasions were staphylococci shown to be resistant to sodium fusidate. This incidence of resistance is similar to that recorded for cephaloridine, cloxacillin, lincomycin, and novobiocin. None of these patients was included in the present trial.

Further analysis of the 1,330 swabs showed that Staph. aureus accounted for $82 \%$ of all organisms isolated. This is similar to the $80 \%$ incidence mentioned by Sneddon (1970). However, almost $50 \%$ of our staphylococci were resistant to penicillin and ampicillin, which is almost the same as the incidence of penicillin resistances found at St. Bartholomew's Hospital by Price et al. (1968).

This relatively high incidence of resistance to penicillin makes the routine use of systemic antibiotics such as Triplopen and procaine penicillin of doubtful value. Cloxacillin is a more logical choice but should probably be used only when there is evidence of infection spread. According to Rutherford et al. (1970), cloxacillin is of doubtful value in the treatment of localized, superficial lesions.

The procedure of introducing fusidic acid gel into an incised abscess cavity is clearly a promising alternative to superficial antibiotic dressings or wicks in the treatment of incised abscesses.

I am grateful to Mr. J. M. Fitton, consultant orthopaedic surgeon in charge of Accident and Emergency Services, Leeds (St. James's) University Hospital Management Committee, for permission to publish this paper. I also thank Mr. P. N. Underwood, of Leo Laboratories, for his valuable help.

\section{References}

Calnan, J., and Fry, H. (1962). British fournal of Pharmacology and Chemotherapy, 19, 321

Cowan, A. (1965). Irish fournal of Medical Science, 6th series, p. 125.

Horth, N., and Thomsen, K. (1967). Acta Allergologica, 21, 487 .

Knight, A. G., Vickers, C. F. H., and Percival, A. (1969). British fournal of Dermatology, 81, Suppl. No. 4, p. 88 .

Meyer-Rohn, J. (1964). Third International Congress of Chemotherapy, 1963. Stuttgart, Thieme.

Price, D. J. E., O'Grady, F. W., Shooter, R. A., and Weaver, P. C. (1968). British Medical Fournal, 3, 407

Ritchie, I. C. (1966). Clinical Trials fournal, 3, 529.

Ritchie, I. C. (1968). British fournal of Clinical Practice, 22, 15.

Rutherford, W. H., Calderwood, J. W., Hart, D., and Merritt, J. D. (1970). Lancet, 1, 1077.

Sneddon, J. (1970). Care of Hand Infections, London, Arnold.

Sobye, P. (1966). Ugeskrift for Laeger, 128, 204.

Taylor, G., and Bloor, K. (1962). Lancet, 1, 935.

\title{
Survey of School Meals
}

\author{
A. E. BENDER, PAMELA MAGEE, A. H. NASH
}

\section{Methods}

\section{SELECTION}

\section{Summary}

A Survey of 48 schools in South-east England showed that the protein and energy contents of the school meals were well below the standards set by the Department of Health. It was found that $7 \cdot 4 \%$ of the children did not have breakfast. One school provided meals twice the average size, and the food was eaten. About $10 \%$ of the food offered was wasted.

\section{Introduction}

A survey of school meals was undertaken between November 1970 and May 1971 in South-east England in order to measure the amount of food consumed and to determine the nutrient intake by calculation from food-composition tables.

Nutrition Department, Queen Elizabeth College, London W.8 A. E. BENDER, PH.D., F.R.I.C., Professor of Nutrition PAMELA MAGEE, B.SC.(NUT.), Research Assistant A. H. NASH, B.SC., Research Assistant
The amount of food consumed depends to a great extent on the menu and method of preparation, age and weight of the individual, and day-to-day variation in appetite. It was hoped to include all these variables by visiting several schools for children of each age group on a single occasion and selecting 20 meals at random in each, irrespective of the number of meals served and the ages of the children. In all, 48 schools were visited -8 infant, 18 infant-and-junior, 12 junior, and 10 senior. Schools were selected for geographical convenience and representative types, and visits were made on all days of the week.

Because of practical difficulties the number of meals weighed reached 20 in only half the schools, in the others the number varied between 9 and 19. Altogether 772 meals were examined. Most schools served between 200 and 300 meals each day.

Children were selected at random, roughly spaced throughout the serving period. Where there was more than one lunch period the sample of 20 was made up with some meals from each period. When there was a choice of dishes a number of each type was included. In each instance there was a main dish and a dessert.

\section{PROCEDURE}

A team of four investigators visited each school. One selected the child whose food was to be examined and brought him and 
his plate to the weigher. The second member of the team weighed each item of food while the third noted the weights. The fourth person rendered help where necessary and later weighed and measured the children. Each child, designated with a numbered ticket, returned his finished plate for measurement of uneaten food. If second helpings were taken they were included in the total eaten.

Food was weighed to the nearest $5 \mathrm{~g}$ on a dietary balance. Energy and nutrient contents were calculated from the food composition tables (McCance and Widdowson, 1960) programmed on the Queen Elizabeth College computer. Recipes were obtained for made-up dishes and the composition of preparations purchased ready-made was obtained from the supplier.

The catering supervisor provided information of food purchased for the day in question or taken from stock. This was the total raw food available. A small number of adults also have meals at school, and to calculate food available per head this number was doubled to arrive at a figure for the total number of child-equivalent meals served. (The Schools Meals Service recommends that adults and senior children are provided with $20 \%$ more food than younger children.)

\section{Results}

Because, as listed above, so many factors affect the amount of food eaten it is not possible to draw conclusions from any one school since on the day measurements were made any of these factors may have modified the normal food consumption pattern. However, the random selection of meals in a group of schools should include all these variables and the average or median figure for each group may, therefore, be a reliable guide to normal food consumption.

\begin{tabular}{|c|c|c|c|c|c|c|c|}
\hline \multirow[b]{2}{*}{$\begin{array}{l}\text { Type of } \\
\text { School }\end{array}$} & \multirow[b]{2}{*}{ No. } & \multicolumn{3}{|c|}{ Energy } & \multicolumn{3}{|c|}{ Protein } \\
\hline & & 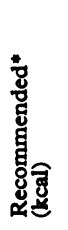 & 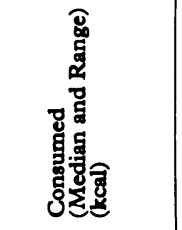 & 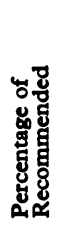 & 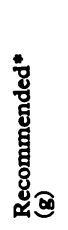 & 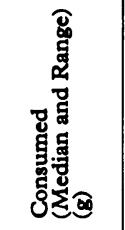 & 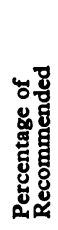 \\
\hline $\begin{array}{l}\text { Infant } \\
\text { Infant/Junior } \\
\text { Junior } \\
\text { Senior }\end{array}$ & $\begin{array}{r}8 \\
18 \\
12 \\
10\end{array}$ & $\begin{array}{l}600 \\
700 \\
750 \\
870\end{array}$ & $\begin{array}{l}420(360-640) \\
480(330-790) \\
475(280-660) \\
650(420-1,340)\end{array}$ & $\begin{array}{l}70 \\
69 \\
63 \\
75\end{array}$ & $\begin{array}{l}23 \\
25 \\
29 \\
33\end{array}$ & $\begin{array}{l}13(10-16) \\
15(11-30) \\
16(8-26) \\
20(11-31)\end{array}$ & $\begin{array}{l}57 \\
60 \\
55 \\
61\end{array}$ \\
\hline
\end{tabular}

- Recommended figures are one-third of the daily recommended intakes for children of the average age of the type of school (Department of Health and Social Security, $880 \mathrm{kcal}$ and $29 \mathrm{~g}$ of protein, as an average.

Table I shows the median (and ranges) of intakes of energy and protein, including second helpings, for each type of school. The average school meal is intended to supply one-third of the day's requirements of energy, $880 \mathrm{kcal}(3.7 \mathrm{MJ})$, and one-half of the protein, $29 \mathrm{~g}$ (Department of Education and Science, 1966). However, as stated in that publication, these figures will vary with the size of portions served to children of different age and sex, and the target figures used in Table $I$ are the recommended intake figures for children of the average age in the school (Department of Health and Social Security, 1969). The energy figures are all lower than $880 \mathrm{kcal}$, except in the senior school age group.

Infant Schools.- The median for these eight schools was $70 \%$ of the energy target $(420 \mathrm{kcal})$ and $57 \%$ of the protein target $(13 \mathrm{~g})$. Thus not only was the amount of food low but, from the protein point of view, the quality was low-that is, increasing the size of portions to meet the energy target would still leave the protein intake below target.
Infant-funior Schools. - In these 18 schools the median energy intake was $69 \%$ of target $(480 \mathrm{kcal})$ and the protein intake was $60 \%$ (15 g).

Funior Schools.-The median energy intake in these 12 schools was the lowest of those measured, being $63 \%$ of target (475 $\mathrm{kcal})$. The median protein intake was also the lowest at $55 \%$ of target (16 g).

Senior Schools. - In these 10 schools the energy intake was the highest, at $75 \%$ of target $(650 \mathrm{kcal})$ and one school reached an average meal size of $1,340 \mathrm{kcal}$. The quality from the protein point of view was similar to that of the other schools and reached $61 \%$ of target $(20 \mathrm{~g})$.

\section{KITCHEN WASTE}

Table II shows the calories and protein available for preparing each meal, calculated by adding the food purchased and food taken from store and dividing by the number of meals served. That this figure is not always reliable is indicated by the finding in three senior schools that the average plate contents were the same as or slightly greater than the amount of food apparently available, and that in four other schools the apparent waste was only $10 \%$. This may be because food taken from store was not accurately recorded.

TABLE II-Preparation Losses (Average and Range)

\begin{tabular}{|c|c|c|c|c|c|c|}
\hline \multirow[b]{2}{*}{$\begin{array}{l}\text { Type of } \\
\text { School }\end{array}$} & \multicolumn{3}{|c|}{ Calories } & \multicolumn{3}{|c|}{ Protein } \\
\hline & $\begin{array}{l}\text { Available } \\
\text { per Meal* }\end{array}$ & $\begin{array}{c}\text { Average } \\
\text { Meal } \\
\text { Offered }\end{array}$ & $\begin{array}{c}\text { Ap- } \\
\text { parent } \\
\text { Kitchen } \\
\text { Waste } \\
(\%)\end{array}$ & $\begin{array}{c}\text { Avail- } \\
\text { able per } \\
\text { Meal* } \\
\text { (g) }\end{array}$ & $\begin{array}{c}\text { Average } \\
\text { Meal } \\
\text { Offered } \\
(\mathrm{g})\end{array}$ & $\begin{array}{c}\text { Ap- } \\
\text { parent } \\
\text { Kitchen } \\
\text { Waste } \\
(\%)\end{array}$ \\
\hline $\begin{array}{l}\text { Infant } \\
\text { Infant/Junior } \\
\text { Junior } \\
\text { Seniort } \quad \ldots\end{array}$ & $\begin{array}{c}800 \\
(530-950) \\
750 \\
(470-1,000) \\
710 \\
(460-1,000) \\
1,000 \\
(630-1,240)\end{array}$ & $\begin{array}{c}510 \\
(410-660) \\
530 \\
(340-700) \\
515 \\
(330-640) \\
930 \ddagger \\
(640-1,340)\end{array}$ & $\begin{array}{c}35 \\
(9-50) \\
29 \\
(6-58) \\
27 \\
(8-47) \\
78\end{array}$ & $\begin{array}{c}26 \\
(13-39) \\
29 \\
(14-39) \\
29 \\
(17-40) \\
29 \\
(21-50)\end{array}$ & $\begin{array}{c}14 \\
(11-17) \\
18 \\
(9-28) \\
18 \\
(12-25) \\
24 \\
(19-33)\end{array}$ & $\begin{array}{c}43 \\
(9-61) \\
42 \\
(3-66) \\
39 \\
(10-60) \\
178\end{array}$ \\
\hline
\end{tabular}

- Food purchased plus food from store divided by number of meals (child equivalents) served.

$\$$ Results from one school showed more on the average plate than was stated to be available.

8 Results unreliable since, in addition to note $\ddagger$, two other schools had zero apparent kitchen waste

The apparent kitchen waste is the difference between the food available per head and the average meal served. This is not true waste since there is often food to spare which is offered as second helpings. This overestimate of waste will not introduce a large error since the number of second helpings is usually only a small proportion of the total. On the other hand, if, as indicated above, the food taken from store was underestimated this would result in an underestimate of apparent waste. The figure for apparent waste also includes food that was not served and was discarded at the end of the day.

One conclusion that can be drawn from Table II is that the total food purchases, allowing $20-30 \%$ for preparation waste in the kitchen, was not adequate to meet the target figures. For the four types of schools these are respectively, 600, 700, 750, and $870 \mathrm{kcal}$ (Table I), which were to be supplied from, respectively, $800,750,710$, and $1,000 \mathrm{kcal}$ of available food.

Preparation losses in schools may be greater than elsewhere since unpalatable food, such as fat from meat, is often trimmed off in the kitchen. However, apparent losses exceeded $45 \%$ of available calories in five schools and exceeded $45 \%$ of available protein in 15 schools, which compares unfavourably with the average figures.

The amount of food left uneaten was very consistent in each type of school. Just under half the children in each group of schools, between 7 and 10 children, left some food and the amount averaged $20 \%$ of the calories and $20 \%$ of the protein 
offered. Thus the average overall wastage amounts to $10 \%$ of the food offered.

Generally, two lunch sittings were served in the lunch break of one to one and a half hours and there was time to eat the meal in a leisurely fashion. In some schools, however, the dining arrangements were of such a crowded and speedy nature that slow eaters were not encouraged to finish their meals. Overall there was no relation between the size of the meal and the amount left uneaten.

\section{INTAKE OF CALCIUM AND IRON}

Table III shows the intake of iron and calcium (median and range). The recommended intake of iron for children is 8 to $16 \mathrm{mg}$, depending on age; the overall average intake from the school meals was $3.6 \mathrm{mg}$, which is between $24 \%$ and $45 \%$ of the daily recommended amount. The overall average calcium intake at $190 \mathrm{mg}$ is between $27 \%$ and $38 \%$ of the daily recommended amount.

TABLE III-Iron, Calcium, and Sugar Intake (Median and Range)

\begin{tabular}{|c|c|c|c|}
\hline Types of & Iron (mg) & Calcium (mg) & Sugar (g) \\
\hline $\begin{array}{l}\text { Infant } \\
\text { Infant/Junior } \\
\text { Junior } \\
\text { Senior }\end{array}$ & $\begin{array}{l}2 \cdot 3(1 \cdot 1-3 \cdot 9) \\
2 \cdot 9(1 \cdot 4-5 \cdot 8) \\
2 \cdot 7(1 \cdot 6-5 \cdot 3) \\
4 \cdot 3(2 \cdot 3-9 \cdot 5)\end{array}$ & $\begin{array}{l}160(90-270) \\
170(100-570) \\
160(90-430) \\
200(70-330)\end{array}$ & $\begin{array}{l}20(9-31) \\
21(13-39) \\
21(3-44) \\
25(13-51)\end{array}$ \\
\hline
\end{tabular}

The variations in mineral intake, both within a school and between schools, are very large and greater than variations in energy intake since the type as well as quantity of food has a pronounced effect on the nutrient intake. In one school the highest individual calcium intake was $430 \mathrm{mg}$ because of the large meal provided-namely, $1,340 \mathrm{kcal}$; the highest in another school was $970 \mathrm{mg}$ because a milk drink was included.

\section{SUGAR}

High sugar intakes are condemned because sugar is a source of energy without nutrients, because it is a cause of dental decay, and because it may be a contributory factor in obesity and certain forms of heart disease. The department of Education and Science (1966) recommended that the amount of sugar should average $18 \mathrm{~g}$ per meal ( $\frac{1}{2} \mathrm{oz}(14 \mathrm{~g})$ sugar and $1 / 5 \mathrm{oz}$ preserves ( $4 \mathrm{~g}$ sugar)). The average meal (all schools) slightly exceeded this figure, being $22 \mathrm{~g}(88 \mathrm{kcal})$. However, this is $17 \%$ of the average calorie intake. In one school sugar intake reached $33 \%$ of the energy intake, and the ranges in Table III show that some schools provided $40-50 \mathrm{~g}$ of sugar in the meal.

The exceptionally high figure of $80 \mathrm{~g}$ of sugar was reached when a child had two helpings of a pudding such as sponge-with syrup. However, the average meal in 14 schools provided $20 \%$ or more of the calories as sugar added in cooking.

\section{Discussion}

While variations in the popularity of the menu, daily fluctuations in the appetite, etc., listed earlier do not allow too much reliance to be placed on the figures obtained for a single school, they are the average of 20 meals and some comparisons may be instructive.

Compared with the target of $33 \%$ of the daily recommended intake of energy, 33 of the 48 schools provided only $25 \%$ or less and nine schools provided less than $20 \%$. Twelve schools provided less than $25 \%$ of the recommended daily protein intake instead of the target of $50 \%$. One school provided meals double the average size, $1,340 \mathrm{kcal}$, with a menu of three energy-rich foods-namely, chips, sausage pie, and ginger sponge. The figures show that this amount can be eaten by some children at least.

Breakfast and School Milk.-The size of the lunch should be considered together with breakfast and mid-morning milk. Of 142 children in infant schools six had no breakfast-that is, nothing more than tea or coffee-and 19 did not take milk midmorning. Of 269 infant-plus-junior children 17 had no breakfast and 75 did not take milk. Of 211 juniors 13 had no breakfast and 62 did not take milk. Of 154 seniors 21 had no breakfast and at that time milk was not available to this age group. In all, $7 \cdot 4 \%$ of the children did not have breakfast (Table IV). The amount of food wasted at lunch did not necessarily bear any relation to whether or not breakfast was eaten.

TABLE IV-Children Not Eating Breakfast and Children Refusing School Milk

\begin{tabular}{|c|c|c|c|c|c|c|}
\hline \multirow{2}{*}{\multicolumn{2}{|c|}{$\begin{array}{l}\text { Type of } \\
\text { School }\end{array}$}} & \multirow{2}{*}{$\begin{array}{l}\text { No. of } \\
\text { Children }\end{array}$} & \multicolumn{2}{|c|}{ No Breakfast } & \multicolumn{2}{|c|}{ No Milk } \\
\hline & & & No. & $\%$ & No. & $\%$ \\
\hline $\begin{array}{l}\text { Infant } \\
\text { Infant/Junior } \\
\text { Junior } \\
\text { Senior }\end{array}$ & $\begin{array}{l}\because \\
\because \\
\therefore\end{array}$ & $\begin{array}{l}142 \\
269 \\
211 \\
154\end{array}$ & $\begin{array}{r}6 \\
17 \\
13 \\
21\end{array}$ & $\begin{array}{r}4 \cdot 2 \\
6 \cdot 3 \\
6 \cdot 2 \\
13 \cdot 6\end{array}$ & $\begin{array}{l}19 \\
75 \\
62 \\
\end{array}$ & $\begin{array}{l}13 \\
28 \\
29 \\
\end{array}$ \\
\hline
\end{tabular}

Sugar.-The school meal was originally planned as a balanced meal-that is, one supplying the required nutrients with a sufficient excess of protein to make up for what may be a poor diet the rest of the day: one-third of the energy and one-half of the protein. The principal factor that "unbalances" most diets in this country is sugar, which accounts on average for one-fifth of the total energy intake. It is likely that the high consumption of sweets, chocolates, cakes, and lemonade by children provides them with an even higher proportion of sugar in their diet. In this respect school meals that provide one-fifth or one-third of the food as sugar are far from achieving a balanced diet. Moreover, the school meal is intended to provide, as well as nourishment, an opportunity for social education and education in good eating habits. A reduction in the amount of sugar used in cooking would be a useful step in teaching better eating habits.

\section{References}

Department of Education and Science (1966). The Nutritional Standard of School Dinners. Circular 3/66. London, H.M.S.O.

Department of Health and Social Security (1969). Recommended Intakes of Nutrients for the United Kingdom. Report No. 120. London, H.M.S.O. McCance, R. A., and Widdowson, E. M. (1960). Medical Research Council. Special Report Series, No. 297. 